\title{
Specific Role of Magnesium Ion in Protecting the Anticomplementary Effect of DNA in Immune Hemolysis ${ }^{1}$
}

\author{
EiJi Okưhara, Junko Igarashi, ${ }^{*}$ Akira Wakizaka and \\ Tsutomu Matsumoto $\dagger$ \\ Department of Biochemistry, Akita University School of Medicine, \\ Akita
}

\begin{abstract}
Okuhara, E., Igarashi, J., Wakizaka, A. and Matsumoto, T. Specific Role of Magnesium Ion in Protecting the Anticomplementary Effect of DNA in Immune Hemolysis. Tohoku J. exp. Med., 1975, $116(1), 33-37$ - When a constant quantity of denatured $\mathrm{DNA}$ required for $\mathrm{C}^{\prime}$-fixation reaction was employed as the antigen, an anticomplementary action of DNA was frequently observed. In order to cope with this difficulty in the analysis of $\mathrm{C}^{\prime}$-fixation, the relationship between $\mathrm{DNA}, \mathrm{Mg}^{2+}$ and $\mathrm{C}^{\prime}$ was investigated. It was found that this phenomenon was closely related to the flexible conformation of DNA which is highly influenced by $\mathrm{Mg}^{2+}$. Further, this effect could be eliminated in the presence of $5 \mathrm{mM} \mathrm{MgCl}$. The mechanism of the elimination by $\mathrm{Mg}^{2+}$ of the anticomplementary effect of DNA was discussed. DNA; complement fixation
\end{abstract}

The $\mathrm{C}^{\prime}$-fixation test has been routinely used for serological analysis of antigen and antibody in our immune system using salmon sperm DNA (ssDNA) as antigen. While examining the nature of rabbit anti-DNA antisera by the $\mathrm{C}^{\prime}$-fixation test, we frequently observed an anticomplementary phenomenon caused by the addition of denatured DNA or oligonucleotides from DNA to the reaction mixture. In 1963, Stollar and Levine mentioned that denatured DNA was anticomplementary for sera from patients with systemic lupus erythematodes (SLE) at concentrations greater than $2.0 \mu \mathrm{g}$ per reaction mixture and that a zone of excess antigen inhibition was not observed for the sera of some patients with SLE, and also that values close to $1.0 \mu \mathrm{g}$ of denatured DNA was optimal for the majority of sera studied. The importance of magnesium ion to the function and conformation of nucleic acids has been long recognized (Sander and Ts'o 1971) and it was conjectured that the trouble with $\mathrm{C}^{\prime}$-fixation might be overcome by changing the concentrations of magnesium ion in the reaction mixture. Now, we have found that a certain amount of magnesium ion in the reaction mxiture

Received for publication, January 20, 1975.

1 This work was supported in part by a research grant from the Ministry of Education of Japan.

* Present address: Department of Biochemistry, Tohoku University School of Medicine, Sendai.

$\uparrow$ Present address: Akita Agricultural College, Akita. 
reduced the anticomplementary action of DNA remarkably. The present paper is a report of the studies on the mode of interaction between the complement and DNA in the presence of magnesium ion.

\section{Materials and Methods}

DNA preparation. Salmon sperm (Oncorhynchus keda) were collected at the Tama River, Akita. The sperm was frozen and stored at $-25^{\circ} \mathrm{C}$ prior to the extraction of DNA. Preparation of DNA from salmon sperm was prepared by the SDS-phenol treatment (Okuhara 1970) of the frozen sperm.

Analyses of DNA preparation. The DNA preparation used had the following composition: protein, $0.5 \%$; RNA, less than $0.5 \% ; \varepsilon(\mathrm{P})_{260}, 6000$. Base composition was adenine 27.97, guanine 20.77 , cytosine 20.95 , and thymine 30.31 . Tm was $81^{\circ} \mathrm{C}$.

Protein was determined by the method of Lowry et al. (1951); RNA, by that of Savitsky and Stand (1965), and phosphorus, by that of Fiske and Subbarow (1925). For the determination of base composition, a sample of DNA was hydrolyzed in a sealed tube with formic acid at $175^{\circ} \mathrm{C}$ for $30 \mathrm{~min}$ and analyzed by a modification of the method of Murakami et al. (1970) using the cation-exchange chromatography. For the measurement of $\mathrm{Tm}, 25 \mu \mathrm{g}$ of DNA were dissolved in $1.0 \mathrm{ml}$ of $0.01 \mathrm{M} \mathrm{NaCl}-0.05 \mathrm{M}$ sodium cacodylate $(\mathrm{pH} 7.0)$ and $\mathrm{Tm}$ was determined by using a Hitachi UV-VIS spectrophotometer 139.

Antiserum. This was produced by repeated immunization of rabbits with thermally denatured ssDNA-methylated bovine serum albumin complex. The detailed procedure was described in our previous paper (Matsumoto and Okuhara 1974).

$C^{\prime}$-fixation. The quantitative $\mathrm{C}^{\prime}$-fixation measurements were made by a modification of Kolmer's micromethod as previously described (Matsumoto and Okuhara 1974). Thermally denatured DNA was employed as the antigen. Hereafter, the term DNA in this paper indicates thermally denatured DNA. The veronal buffer used here as the diluent contained $0.55 \mathrm{mM} \mathrm{MgCl}_{2}$.

\section{RESULTS}

The anticomplementary effect of ssDNA in immune hemolysis is shown in Fig. 1. When freshly prepared ssDNA in excess of $4 \mu \mathrm{g}$ was added incomplete hemolysis occurred, while with the ssDNA* 30-day-old after extraction, even as small as $0.5 \mu \mathrm{g}$ of ssDNA caused the anticomplementary action, and this action became potent in parallel with the increase of the antigen. However, as shown in Fig. 2, the anticomplementary effect was reduced gradually with the addition of increasing amounts of $\mathrm{MgCl}_{2}$. The curves in Fig. 2 represent respectively the effect of $\mathrm{Mg}^{2+}$ added in a range of 0.5 to $5 \mathrm{mM}$ on the anticomplementary action of four different concentrations of DNA. It can be seen in each curve that the hemolytic activity increased with the increase of $\mathrm{Mg}^{2+}$ added; at $5 \mathrm{mM}$ of $\mathrm{Mg}^{2+}$ $100 \%$ lysis occurred, indicating that the anticomplementary action of DNA in a range of 0.5 to $10.0 \mu \mathrm{g}$ was completely eliminated. In an experiment not reported here, $20.0 \mu \mathrm{g}$ of NDA were added as the antigen in the presence of 5 $\mathrm{mM} \mathrm{Mg}^{2+}$, but again no anticomplementary effect was observed. Thus $5 \mathrm{mM}$ should be the optimal concentration of $\mathrm{Mg}^{2+}$.

\footnotetext{
* This DNA was used as antigen in experiments shown in Fig. 3 and Table 1.
} 


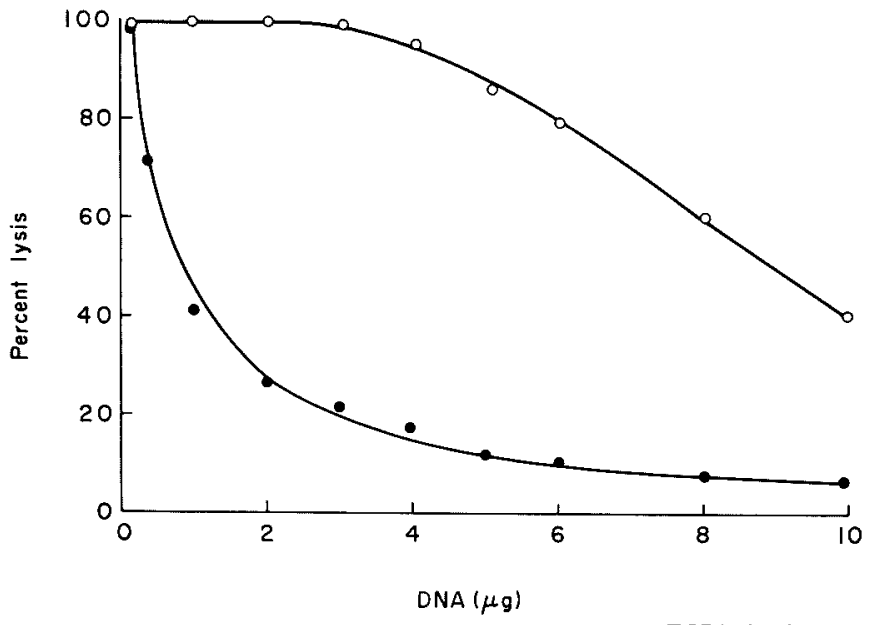

Fig. 1. Anticomplementary effect of thermally denatured ssDNA in immune hemolysis. $0.1 \mathrm{ml}$ of the antiserum appropriately diluted with veronal buffer, $0.1 \mathrm{ml}$ of antigen ( 1 to $10 \mu \mathrm{g}$ of ssDNA $/ \mathrm{ml}$ of $0.15 \mathrm{M} \mathrm{NaCl}$ ) and $0.2 \mathrm{ml}$ of $\mathrm{C}^{\prime}(2$ units) were mixed, and the fixation was allowed to proceed for $18 \mathrm{hr}$ at $4^{\circ} \mathrm{C}$. Then, $0.2 \mathrm{ml}$ of a $(3$ units of hemolysin)-(red cells) mixture was added and the whole mixture was incubated at $37^{\circ} \mathrm{C}$ for $30 \mathrm{~min}$. $\circ$, freshly prepared ssDNA; •, ssDNA 30 days old after extraction.

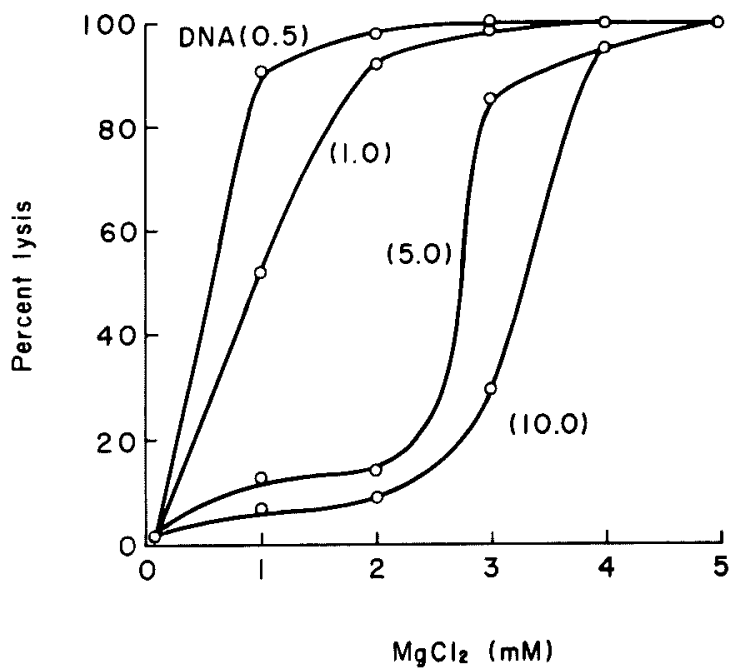

Fig. 2. Influence of $\mathrm{Mg}^{2+}$ to the anticomplementary effect of denatured DNA $(\mu \mathrm{g})$.

To explore the above findings, the experiments in Fig. 3 were carried out. In Fig. 3A, the concentration of $\mathrm{C}^{\prime}$ was kept constant ( 2 or 6 units) and the concentrations of DNA and $\mathrm{Mg}^{2+}$ were varied. The magnesium concentration required for $50 \%$ hemolysis increased in parallel with the increase of DNA added. With 2 units of C', the effect of $\mathrm{Mg}^{2+}$ was remarkable. Fig. 3B indicates that when 
(A)

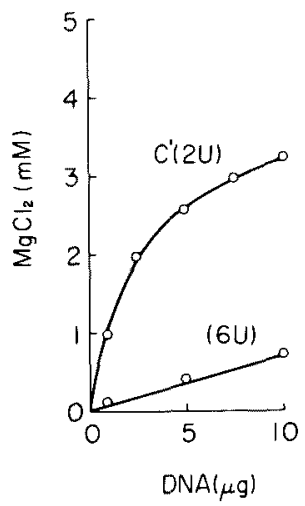

(B)

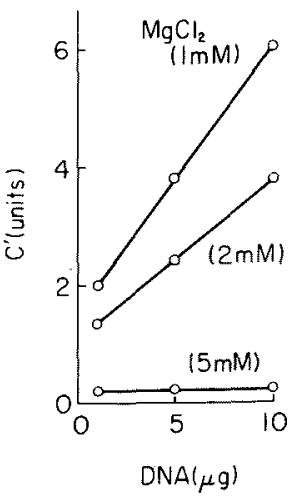

(C)

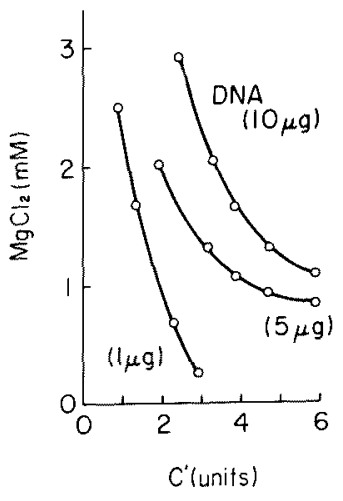

Fig. 3. Relationships between the amounts of $\mathrm{C}^{\prime}, \mathrm{Mg}^{2+}$ and DNA.

TABLE 1. Effect of preincubation of $C^{\prime}$ with $D N A$ and $M g^{2+}$ on the hemolytic action

\begin{tabular}{clrrr}
\hline Exp. No. & \multicolumn{2}{c}{ Preincubation $\left(37^{\circ} \mathrm{C}, 10 \mathrm{~min}\right)$} & $\begin{array}{c}\text { Incubation } \\
\left(37^{\circ} \mathrm{C}, 30 \mathrm{~min}\right)\end{array}$ & $\begin{array}{c}\text { Hemolysis } \\
(\%)\end{array}$ \\
\hline 1 & $\mathrm{C}^{\prime}$ & $\left(-\mathrm{DNA},-\mathrm{Mg}^{2+}\right)$ & $+\mathrm{EA}$ & 100 \\
2 & $\mathrm{C}^{\prime}+\mathrm{DNA}$ & $\left(-\mathrm{Mg}^{2+}\right)$ & $+\mathrm{EA}$ & 70 \\
3 & $\mathrm{C}^{\prime}+\mathrm{Mg}^{2+}$ & $(-\mathrm{DNA})$ & $+\mathrm{EA}$ & 100 \\
4 & $\mathrm{C}^{\prime}+\mathrm{Mg}^{2+}+\mathrm{DNA}$ & & $+\mathrm{EA}$ & 100 \\
5 & $\mathrm{C}^{\prime}+\mathrm{Mg}^{2+}$ & $(-\mathrm{DNA})$ & $+\mathrm{EA}+\mathrm{DNA}$ & 100 \\
6 & $\mathrm{C}^{\prime}+\mathrm{DNA}$ & $\left(-\mathrm{Mg}^{2+}\right)$ & $+\mathrm{EA}+\mathrm{Mg}^{2+}$ & 70 \\
\hline
\end{tabular}

* Sensitized sheep erythrocytes.

the concentration of $\mathrm{Mg}^{2+}$ was relatively low ( $2 \mathrm{mM}$ or $1 \mathrm{mM}$ ), the consumption of $\mathrm{C}^{\prime}$ increased with the addition of increasing amounts of DNA. At the optimal concentration of $\mathrm{Mg}^{2+}(5 \mathrm{mM}), 2$ units of $\mathrm{C}^{\prime}$ were sufficient to produce the usual hemolysis. Fig. $3 \mathrm{C}$ indicates that when the amount of DNA was kept constant (1.5 or $10 \mu \mathrm{g}$ ), the concentration of $\mathrm{Mg}^{2+}$ required decreased with the increase in the amount of $\mathrm{C}^{\prime}$. The results in Fig. 3 revealed that the extent of hemolysis largely depends on the concentration of $\mathrm{Mg}^{2+}$ in the projected hemolytic system. Then, the protective effect of $\mathrm{Mg}^{2+}$ was further investigated and the results are shown in Table 1. When $\mathrm{C}^{\prime}$ alone was incubated with the hemolytic system, $100 \%$ hemolysis occurred (Exp. 1). When $\mathrm{C}^{\prime}$ was preincubated only with DNA and the mixture was incubated with hemolytic system, the extent of hemolysis was $70 \%$ (Exp. 2). As seen especially in Exp. 4, when $\mathrm{Mg}^{2+}$ did exist with $\mathrm{C}^{\prime}$ prior to the addition of $\mathrm{DNA}, \mathrm{Mg}^{2+}$ acted protectively. However, when $\mathrm{Mg}^{2+}$ was added after $\mathrm{C}^{\prime}$ and DNA were mixed together, it failed to exert a protective effect (Exp. 6). Apparently $\mathrm{Mg}^{2+}$ inhibited the inactivation of $\mathrm{C}^{\prime}$ by $\mathrm{DNA}$. 


\section{Discussion}

Our results have demonstrated that the anticomplementary action of DNA can be eliminated by the addition of more than $5 \mathrm{mM} \mathrm{M} \mathrm{Mg}^{2+}$. The data obtained by kinetic studies showed that $\mathrm{Mg}^{2+}$ actually functioned as a "protective agent" and prevented non-specific binding between $\mathrm{C}^{\prime}$ and DNA. The results can be interpreted as follows: Some change in the electrostatic state within the DNA molecule leads to the inactivation of $\mathrm{C}^{\prime}$, whereas in the presence of $\mathrm{Mg}^{2+}$, the stabilized structure which is responsible for the antigenic activity and has no anticomplementary action may be restored. We have also observed that when the DNA solution was kept at $4^{\circ} \mathrm{C}$, the anticomplementary effect of DNA increased with time (data not shown). Moreover, when the DNA which was extracted from frozen salmon sperm by the method of SDS-phenol treatment (Okuhara 1970) was stored at $-20^{\circ} \mathrm{C}$ and dissolved in $0.15 \mathrm{M} \mathrm{NaCl}$, less than $1.0 \mu \mathrm{g}$ of DNA was sufficient to exhibit the anticomplementary action, and this effect was retained even after the DNA was preserved for 100 days. The same phenomenon was observed when DNA in $70 \%$ ethanol was kept at $-20^{\circ} \mathrm{C}$. In addition, we have evidence that the difference in the extent of the anticomplementary effect of DNA was depandent on the preparation obtained and kinds of starting material employed. Actually, no anticomplementary action was observed when $20 \mathrm{mg}$ of DNA prepared from mouse embryos were used as antigen in immune hemolysis. It would be of interest to investigate in what manner the DNA acts on each component of the complement system.

As the anticomplementary phenomenon caused by DNA as described in the present paper is closely related to the extent of denaturation of DNA preparations, it seems possible to examine structural changes of DNA preparations by measuring the anticomplementary effect serologically.

\section{References}

1) Fiske, C.H. \& Subbarow, Y. (1925) The colorimetric determination of phosphorus. J. biol. Chem., 66, 375-400.

2) Lowry, O.H., Rosebrough, N.J., Farr, A.L. \& Randall, R.J. (1951) Protein measurement with the Folin phenol reagent. J. biol. Chem., 193, 265-275.

3) Matsumoto, T. \& Okuhara, E. (1974) Separation and characterization of immunoglobulin classes of antisalmon sperm deoxyribonucleic acid antibodies in rabbits. Tohoku J. exp. Med., 113, 245-255.

4) Murakami, F., Rokushika, S. \& Hatano, H. (1970) Cationexchange chromatography of nucleotides, nucleosides and nuclec bases. $J$. chromatog., 53, $584-586$.

5) Okuhara, E. (1970) Preparation of mammalian DNA by SDS-phenol treatment. Analyt. Biochem., 37, 175-178.

6) Sander, C. \& Ts'o, P.O.P. (1971) Interaction of nucleic acids. VIII. Binding of magnesium ions by nucleic acids. J. mol. Biol., 55, 1-21.

7) Savitsky, J.P. \& Stand, F. (1965) A simple method for measuring ribonucleic acid content of preparations of DNA. Nature (Lond.), 207, 758-759.

8) Stollar, D. \& Levine, L. (1963) Antibodies to denatured deoxyribonucleic acid in lupus erythematosus serum. Arch. Biochem. Biophys., 101, 417-422. 